\title{
ASPEK HUKUM PERLINDUNGAN VARIETAS TANAMAN DITINJAU DARI UNDANG-UNDANG NOMOR 29 TAHUN 2000 TENTANG PERLINDUNGAN VARIETAS TANAMAN
}

\author{
Dwi Afni Maileni \\ Dosen Tetap Prodi Ilmu Hukum UNRIKA
}

Bidang pertanian di Indonesia merupakan salah satu bidang yang dapat dikembangkan sebagai sarana untuk terlibat secara aktif dalam perdagangan internasional, mengingat hasil-hasil pertanian merupakan komoditi ekspor yang sangat dibutuhkan di berbagai manca negara. Hal ini dapat terwujud jika seluruh komponen bangsa bersatu dalam membangun pertanian yang tangguh dan mampu berkompetisi dengan hasil-hasil pertanian negara-negara lainnya, baik dari segi kualitas maupun harga. Sebaliknya jika tidak ada komitmen untuk membangun pertanian yang tangguh, maka Indonesia justru dapat menjadi pasar bagi hasil-hasil pertanian dari negaranegara lain.

Hasil-hasil pertanian seperti buah-buahan dan sayur mayur dari negara lain dapat masuk dengan mudah ke negara lain karena semakin berkurangnya hambatan tarif (tariff barrier) dan non tarif (non tariff barrier). Semakin banyaknya buah dan sayur impor yang beredar di pasar, secara potensial dapat mengancam petani lokal yang tidak siap berkompetisi.

Sehubungan dengan arah kebijakan ekonomi, maka perlu diciptakan iklim yang kondusif untuk perkembangan sektor pertanian di Indonesia sehingga dapat menjaga keseimbangan berbagai kepentingan yang terkait. Kehidupan sektor pertanian yang tangguh akan menjadi landasan bagi bangsa Indonesia untuk melaksanakan pembangunan sektor-sektor lainnya.

Sementara itu, perkembangan pasar di bidang ekonomi, sosial dan teknologi makanan telah mengakibatkan masalah pangan menjadi masalah yang berdimensi global. Ilmu pengetahuan dan teknologi di bidang pangan telah maju dengan pesat, sehingga permasalahannya tidak hanya tertuju pada produk pangan yang dapat dijadikan komoditi yang potensial bagi peningkatan pendapatan masyarakat dan negara, tetapi juga pada sumber penghasil pangan itu sendiri yang dapat direkayasa seperti terciptanya varietas-varietas baru tanaman yang dapat menghasilkan produk-produk unggulan.

Kemampuan untuk menghasilkan varietas baru khususnya varietas unggul bermutu masih rendah di Indonesia. Padahal varietas merupakan salah satu faktor yang sangat menentukan kuantitas dan kualitas produk pertanian. Penggunaan varietas yang memiliki sifat-sifat unggul yang diinginkan merupakan teknologi andalan yang secara luas digunakan oleh masyarakat, relatif murah, dan memiliki kompatibilitas yang tinggi dengan teknologi yang maju lainnya dan tidak mencemari lingkungan. Di samping itu melalui penggunaan varietas unggul diharapkan proses produksi menjadi lebih efisien serta produktivitas dan mutu hasil menjadi lebih baik. Hal ini tentunya dapat berdampak pada produk pertanian dalam negeri memiliki daya saing global yang tinggi.

Salah satu faktor utama yang mengakibatkan masih relatif terbatasnya invensi varietas unggul baru adalah kondisi yang tidak kondusif bagi perkembangan kegiatan pemuliaan. Sebagian besar penelitian masih dilakukan oleh lembaga pemerintah dan perguruan tinggi, sedangkan kalangan industri benih belum berperan secara optimal. Hal ini terjadi karena tidak 
ada jaminan untuk memperoleh keuntungan apabila melakukan kegiatan pembentukan varietas unggul baru.

Perwujudan iklim yang mampu mendorong semangat penemuan dan sekaligus memberikan perlindungan hukum, maka ketentuan penemu varietas tanaman disusun dalam suatu Undang-Undang. Suatu varietas tanaman dihasilkan melalui perakitan yang lazim disebut pemuliaan tanaman. Pemuliaan adalah suatu proses dan juga menghasilkan produk.

Sebagai seorang pemulia, diperlukan penguasaan ilmu dan teknologi serta memerlukan pencurahan pikiran, tenaga, waktu dan dana yang cukup besar. Rumitnya kegiatan ini mengharuskan adanya penghargaan atas hasil invensi para pemulia melalui pemberian jaminan perlindungan hukum yang jelas dan tegas. Adanya kepastian hukum akan mendorong para pemulia lebih giat melakukan penelitian untuk menghasilkan varietas baru tanaman yang lebih unggul.

Ketentuan hukum di Indonesia yang memberikan perlindungan bagi varietas tanaman adalah Undang-Undang Nomor 29 Tahun 2000 tentang Perlindungan Varietas Tanaman. Dalam Undang-Undang Perlindungan Varietas Tanaman, hak khusus yang diberikan sebagai perlindungan dan pengakuan hak disebut hak perlindungan varietas tanaman yang lazim disebut "hak pemulia".

\section{Ruang Lingkup Penemuan Varietas Tanaman}

Hak kekayaan intelektual merupakan hak kebendaan, hak atas sesuatu benda yang bersumber dari hasil kerja otak atau hasil dari pekerjaan pemikiran manusia yang menalar. Hak kekayaan intelektual (Intellectual Property Rights) dapat dideskripsikan sebagai hak atas kekayaan yang lahir karena kemampun intelektual manusia. McKeough and Stewart mendefinisikan hak kekayaan intelektual sebagai hak yang memberikan perlindungan hukum atas hasil kreavitias manusia yang memiliki manfaat ekonomi. Definisi lain mengenai hak kekayaan intelektual adalah hak hukum privat yang memberikan penghargaan atas konstribusi manusia tidak berwujud yang akan digunakan untuk memproduksi suatu teknologi yang sifatnya khusus.

Menurut Pasal 1 angka 3 Undang-Undang Nomor 29 Tahun 2000 tentang Perlindungan Varietas Tanaman disebutkan bahwa varietas tanaman adalah sekelompok tanaman dari suatu jenis atau spesies yang ditandai oleh bentuk tanaman, pertumbuhan tanaman, daun, bunga, buah, biji, dan ekspresi karakteristik genotipe atau kombinasi genotipe yang dapat membedakan dari jenis atau spesies yang sama oleh sekurang-kurangnya satu sifat yang menentukan dan apabila diperbanyak tidak mengalami perubahan.

Berdasarkan pengertian di atas, maka dapat diketahui bahwa varietas tanaman yang dihasilkan harus berbeda dengan varietas tanaman yang lain yang ditandai dengan perbedaan bentuk fisik sampai perbedaan karakteristik tanaman.

Pengaturan mengenai perlindungan terhadap varietas tanaman (new varities of plants protection) merupakan perkembangan dari segi hukum yang ingin menciptakan hak-hak baru guna menegaskan dan memperkuat tipe perlindungan untuk ide berupa konsep hak yang baru.

Kegiatan pemuliaan tanaman merupakan rangkaian kegiatan penelitian dan pengujian atau kegiatan penemuan dan pengembangan suatu varietas, sesuai dengan metode baku untuk menghasilkan varietas baru dan mempertahankan kemurnian benih varietas yang dihasilkan, yang dilakukan dengan tujuan untuk mendapatkan suatu varietas tanaman baru yang bersifat unggul. Pemuliaan tanaman dapat juga diartikan sebagai rangkaian kegiatan untuk 
mempertahankan kemurnian jenis dan/atau varietas tanaman yang sudah ada, atau menghasilkan jenis dan/atau varietas. tanaman baru yang lebih baik. Pada dasarnya pemuliaan tanaman merupakan suatu metode yang secara sistematik merakit keragaman genetik menjadi suatu bentuk yang bermanfaat bagi kehidupan manusia. berikut :

Dalam rangka melakukan kegiatan pemuliaan tanaman, maka harus dipenuhi hal-hal

1. Adanya keragaman genetik

2. Sistem-sistem logis dalam pemindahan dan fiksasi gen

3. Konsepsi dan tujuan sasaran yang jelas

4. Mekanisme penyebarluasan hasilnya kepada masyarakat.

Setelah memperoleh keanekaragaman genetik melalui proses perkawinan tanaman, maka dibuatlah suatu tindakan isolasi atau pemisahan antara suatu spesies dan diadakan pengembangan secara terpisah antara genotipe yang terpilih. Pengujian dan penelitian dipllrukan untuk memilih genotipe, hal ini dilakukan dengan cara melakukan pengukuran fenotipe individu atau kelompok individu sejenis. Penilaian terhadap ragam genotipe dilaksanakan dengan perkawinan tanaman untuk memperbanyak. Kemurnian gen diperoleh melalui teknik pengawan yang ketat untuk mengetahui ada atau tidaknya pengaruh dari komponen lingkungan sekitar.

Secara umum tujuan utama dari pemuliaan tanaman adalah untuk mendapatkan varietas tanaman yang lebih baik dengan cara memperbaiki sifat-sifat tanaman, baik secara kualitatif maupun kuantitatif, walaupun tidak dapat dipungkiri bahwa yang menjadi tujuan akhir adalah sektor ekonomi. Hal ini disebabkan dengan meningkatnya nilai dan jumlah hasil pertanian yang akan diperoleh, maka keuntungan yang lebih besar juga dapat diperoleh. Tujuan dari pemulian tanaman dapat tercapai apabila varietas baru yang dihasilkan oleh pihak pemuliaan tanaman dapat tercapai apabila varietas baru yang dihasilkan oleh pihak pemulia tanaman besar-besar dapat digunakan para petani.

Kegiatan pemuliaan dalam bidang pertanian bertujuan untuk :

1.Perbaikan daya hasil dan stabilitas hasil pada tanaman bahan pangan

2.Perbaikan daya hasil yang lebih menarik pada tanaman buah-buahan

3.Penemuan bahan pangan baru ( diversifikasi menu )

4.Peningkatan protein melalui peningkatan komposisi hasil

5.Peningkatan gizi melalui eksploitasi ragam genetik

6.Peningkatan hasil pertanian yang mempunyai kandungan energi tinggi

7.Perbaikan terhadap kandungan racun

8.Ketahanan terhadap penyakit dan hama di lapangan dan tempat penyimpanan.

Dalam proses pemulian tanaman, yang menjadi subjek yang perlu mendapat perlindungan hukum adalah pihak pemulia yaitu orang-orang yang menjadi objek dalam pemulian tanaman adalah varietas tanaman. Pengertian dari varietas tanaman dapat dirumuskan sebagai berikut .

Sekelompok tanaman dari suatu jenis atau spesies yang ditandai oleh bentuk tanaman, pertumbuhan tanaman, daun, bunga, buah, biji, dan ekspresi karakteristik genotipe atau 
kombinasi genotipe yang dapat membedakan dari jenis atau spesies yang sama oleh sekurangkurangnya satu sifat yang menentukan dan apabila diperbanyak tidak mengalami perubahan.

Hal penting yang turut menunjang perkembangan di bidang pemuliaan tanaman adalah adanya investasi dana. Berkaitan dengan kegiatan investasi akan memberikan suatu hak eksklusif berupa hak pemulia (breeder's rights ) kepada para pemulia tanaman, dengan tujuan untuk :

1. memberikan kesempatan kepada para pemulia termasuk lembaga pemerintahan, untuk mendapatkan suatu pengembalian yang wajar dari dana yang telah mereka keluarkan selama proses pemuliaan

2. memberikan instensif untuk melanjutkan atau menambah investasi dimasa mendatang

3. mengakui hak moral dari inventor ( pihak pemulia yang bersangkutan ) dan hak ekonomi sebagai imbalan atas hasil usahanya.

Keberadaan inventor modal dalam rangka pengembangan pemuliaan sangat penting, untuk itu investor pada umumnya akan meneliti seberapa jauh perlindungan yang akan diberikan bagi hasil penelitian. Hal ini disebabkan karena menyangkut sejumlah dana yang akan dikeluarkan bagi penelitian dan pengembangan varietas baru tanaman melalui kegiatan pemuliaan. Tidak adanya jaminan pengembalian keuntungan dari investasi yang akan ditanamkan akan kelemahan keinginan para investor. Oleh karena itu, maka perlindungan hukum terhadap varietas tanaman perlu diberikan, agar para investor tidak ragu menanamkan modalnya dalam kegiatan penelitian dan pengembangan varietas- varietas tanaman baru yang lebih baik dan unggul.

Perlindungan hukum di bidang pertanaian sudah lama dibutuhkan karena melalui proses pemuliaan tanamant elah diperoleh hasil yang sangat berarti berupa benih tanaman yang bersifat unggul. Dengan adanya proses yang dipengaruhi penyerbukan dan seleksi tanaman, manusia dapat mempengaruhi sifat-sifat varietas tanaman dan bahkan menciptakan varietas tanaman yang baru. Akan tetapi untuk menghasilkan varietas tanaman yang baru atau unggul, diperlukan banyak waktu, usaha dan dana yang cukup besar, sehingga jika tidak ada perlindungan hukum yang jelas akan menimbulkan ketidakpuasan bagi para pemulia tanaman.

Sebagaimana halnya bentuk perlindungan atas hak kekayaan intelektual lainnya, peraturan tentang hak pemulia (bredder's rights) berusaha untuk mendapatkan keseimbangan antara kepentingan pihak yang menghasilkan varietas tanaman dengan pengguna atau konsumen dari jenis varietas tanaman maupun hasil panen dari varietas tanaman tersebut. Apabila perlindungan hukum tidak diberikan, maka perusahaan benih akan mengalami kerugian disebabkan tidak adanya investasi dana dalam yang besar untuk kegiatan penelitian dan pengembangan jenis varietas- varietas tanaman tanaman baru. Secara alamiah setiap varietas tanaman dapat dengan mudah diproduksi ulang, sehingga tanpa adanya jaminan perlindungan hukum, memudahkan pihak ketiga menjual hasil dari varietas tanaman dengan harga rendah tanpa harus melakukan investasi dana yang besar untuk kegiatan pemuliaan.

Hak pemulia yang diberikan untuk perlindungan terhadap varietas tanaman berbeda dengan hak paten, dimana hak paten diberikan untuk melindungi suatu invensi dibidang industri yang terbentuk karena tindakan manusia dan karenanya dapat diteliti dan diproduksi ulang secara identik sedangkan hak pemulia diberikan untuk melindungi suatu produk alam yang sulit dijelaskan dan seringkali berulang secara tidak sama (identik) dan manusia hanya dapat mempengaruhinya saja.

Pada dasarnya perlindungan hukum hanya diberikan terhadap varietas tanaman dari jenis atau spesies tanaman yang baru, unik, seragam, stabil dan diberi nama. Suatu varietas tanaman 
dianggap baru apabila pada saat penerimaan permohonan hak Perlindungan varietas tanaman, bahan perbanyakan atau hasil panen dari varietas tanaman tersebut belum pernah diperdagangkan di Indonesia, atau jika sudah pernah diperdagangkan maka jangka waktunya tidal lebih dari setahun dan jika sudah diperdagangkan di luar negeri, jangka waktunya tidak lebih dari empat tahun untuk tanaman semusim dan enam tahun untuk tanaman tahunan. Varietas tanaman dianggap unik apabila pada saat penerimaan permohonan hak Perlindungan Varietas Tanaman (PVT), varietas tanaman dapat dibedakan secara jelas dengan varietas tanaman lain yang keberadaannya sudah diketahui secara umum.

Varietas tanaman dianggap seragam apabila sifat-sifat utama atau yang penting pada varietas tanaman terbukti seragam, meskipun hasil yang diperoleh bervariasi sebagai akibat daricara tanam dan lingkungan yang berbeda-beda. Varietas tanaman dianggap stabil apabila sifat-sifatnya tidak mengalami perubahan setelah ditanam berulang-ulang dan untuk yang diperbanyak melalui siklus perbanyakan khusus, tidak mengalami perubahan pada setiap akhir siklus tersebut.

Maksud dari varietas tanaman yang diperbanyak tidak mengalami perubahan adalah varietas tanaman harus tetap stabil dalam proses perbanyakan benih atau propagasi dengan metode tertentu, misalnya produksi benih hibrida, kultur jaringan atau stek.

Varietas tanaman yang diberikan perlindungan hukum harus mendapat penamaan yang selanjutnya menjadi nama varietas tanaman yang bersangkutan dengan ketentuan :

1. Nama varietas tanaman tersebut tetap dapat digunakan meskipun masa perlindungan telah habis.

2. Pemberian nama tidak boleh menimbulkan kerancuan terhadap sifat-sifat varietas

3. Penamaan varietas dilakukan oleh pemohon hak Perlindungan Varietas Tanaman (PVT) dan didaftarkan pada kantor Perlindungan Varietas Tanaman (PVT)

4. Apabila penanam tidak sesuai dengan ketentuan butir b, maka kantor Perlindungan Varietas Tanaman (PVT) berhak menolak penamaan tersebut dan meminta penamaan baru

5. Apabila nama varietas tersebut telah dipergunakan oleh varietas lain, maka pemohon wajib mengganti nama varietas tersebut.

6. Nama varietas yang diajukan sebagai merek dagang sesuai dengan peraturan perundangundangan yang berlaku.

Perkembangan terhadap pengakuan hak pemulia memberikan keuntungan yang besar bagi para pemulia tanaman, keuntungan semakin bertambah dengan perubahan pada hak paten yang telah diperluas cakupannya. Hak paten telah memungkinkan adanya hak monopoli atas gen-gen secara individual bahkan juga atas sifat-sufat genetis. Hak tersebut memungkinkan adanya tuntutan ganda (multiple claim), yang tidak hanya meliputi seluruh tanaman tetapi juga bagian-bagian tanaman dan prosesnya.

Perlindungan HAKI bagi tanaman (kepemilikan eksklusif dari beberapa aspek tanaman) cenderung pada bahan tanaman yang tidak ada akhirnya. Pemegang hak pemulia tidak dapat menetapkan harga tertentu dengan bebas karena kekayaan mereka dapat digantikan dengan hal yang sama di satu sisi dan di sisi yang lain pemulia dapat melarang pihak lain untuk mempergunakan (menjual) produk yang mereka lindungi. Dengan demikian, kemampuan HAKI tidak memberikan kekuasaan tanpa batas untuk menyediakan sumber genetik tanaman bagi industri, akan tetapi meskipun demikian adanya HAKI sangat membantu dan diperlukan. Adanya HAKI tidak hanya berguna untuk membedakan, tetapi juga untuk menyebarkan ide dan plasma nutfah, dimana plasma nutfah merupakan sumber daya yang menjadi bahan utama dalam proses 
pemuliaan tanaman. Kedua tindakan tersebut sangat dibutuhkan oleh industri perbenihan dan para pihak lain yang memberi perhatian bagi kegiatan pemuliaan tanaman. Plasma nutfah adalah substansi yang terdapat dalam kelompok makhluk hidup dan merupakan sumber sifat keturunan yang dapat dimanfaatkan dan dikembangkan atau dirakit untuk menciptakan jenis unggul atau kultivar baru. Plasma nutfah dikuasai oleh negara dan dimanfaatkan sebesar-besarnya untuk kemakmuran rakyat. Kultivar merupakan sekelompok tumbuhan yang apabila dibudidayakan untuk memperoleh keturunan akan tetap menurunkan ciri-ciri khas tumbuhan induknya, seperti bentuk, rasa buah, warna dan ciri khas lainnya.

Perlindungan terhadap varietas tanaman berupa bentuk hak pemulia diharapkan harus mampu:

1. Menjamin terpenuhinya sebanyak mungkin kebutuhan petani akan benih yang bermutu secara berkesinambungan dan merata di seluruh wilayah pertanaman secara spesifik.

2. Mendorong dan meningkatkan peran serta masyarakat dan mendorong tumbuhnya industri perbenihan dan mendorong invensi serta pengembangan varietas-varietas baru tanaman sebanyak mungkin oleh masyarakat.

3. Mendorong perluasan lapangan kerja baru di bidang pertanian dan meningkatkan kegiatan teknologi pemuliaan oleh masyarakat.

4. Menjamin perkayaan, pemanfaatan dan pelestarian plasma nutfah.

5. Mendorong peningkatan pendapatan dan taraf hidup petani.

\section{Hak Eksklusif Dalam Perlindungan Varietas Tanaman}

Sebagaimana diketahui bahwa hak pemulia (varietas baru tanaman) merupakan suatu hak yang bersifat eksklusif.Secara prinsip eksklusif varietas hak pemulia meliputi kewenangan pemulia untuk memproduksi atau memperbanyak benih, menyiapkan untuk tujuan propagasi, mengiklankan, menawarkan, menjual atau memperdagangkan, mengekspor, mengimpor dan mecabang untuk keperluan kegiatan-kegiatan tersebut.

Adanya hak eksklusif bagi pemegang hak pemulia mempunyai konsekuensi bahwa orang lain tidak dapat melakukan kegiatan yang bersifat komersial terhadapvarietas tanaman yang telah dilindungi tanpa persetujuan pemegang hak bersangkutan.

Hak eksklusif yang dimiliki melalui hak pemulia dibatasi oleh kegiatan-kegiatan yang tidak dianggap sebagai pelanggaran apabila dilakukan oleh pihak lain tanpa adanya persetujuan dari pemegang hak pemulia. Adapun kegiatan kegiatan yang dianggap tidak melanggar adalah :

1.Menggunakan sebagian hasil panen dari varietas yang dilindungi sepanjang tidak untuk tujuan komersil.

2.Menggunakan varietas yang dilindungi untuk kegiatan penelitian, pemuliaan tanaman dan perakitan varietas baru.

3.Penggunaan oleh pemerintah atas varietas yang dilindungi dalam rangka kebijakan pengadaan pangan dan obat-obatan dengan memperhatikan hak-hak ekonomi dan pemegang hak PVT.

Berdasarkan hak eksklusif yang dimiliki, maka pemegang hak pemulia atau hak PVT dapat mengalihkan hak perlindungan kepada pihak lain yang dianggap mampu melaksanakannya. Pengalihan hak kepada pihak lain dilakukan melalui lisensi yang diatur berdasarkan UU PVT dimana pemberian lisensi dilakukan melalui perjanjian lisensi. Berbeda dengan pengalihan hak PVT melalui pewarisan, hibah, wasiat, perjanjian dalam bentuk akta notaris dan sebab lain yang dibenarkan undang-undang,61 dimana kepemilikan hak juga 
mengalami peralihan, pemberian lisensi melalui perjanjian pada dasarnya hanya pemberian hak untuk menikmati manfaat ekonomi dari hak PVT dalam jangka waktu tertentu dan syarat tertentu pula. Kepemilikan hak PVT tetap berada pada pemegangnya, tidak dialihkan kepada lisensi. Dengan demikian, pemegang lisensi tidak boleh memberikan lisensi kepada orang lain.

Pemegang hak PVT berhak memberi lisensi kepada pihak ketiga, maka apabila terjadi perjanjian lisensi, harus dinyatakan secara tegas dalam perjanjian, yang harus menerangkan hak apa saja yang berpindah kepada pemegang lisensi selama jangka waktu sesuai dalam perjanjian lisensi. Pemegang hak PVT yang akan membuat perjanjian lisensi dengan pihak ketiga lainnya, hanya boleh mengalihkan hak yang belum diberikan lisensi. Pemegang hak PVT wajib memberitahukan kepada para pemegang lisensi atas pemberian lisensi baru.

Selain lisensi yang diperoleh berdasarkan kesepakatan para pihak, dalam UU PVT juga diatur mengenai lisensi wajib. Lisensi wajib terjadi kerana keputusan pemerintah, mislnya untuk mengatasi kelangkaan pangan di musim kemarau, maupun atas dasar permohonan pihak lain karena tidak dilaksanakannya hak PVT. Surat perjanjian yang dilakukan oleh pemberi lisensi hak pemulia kepada penerima lisensi maupun lisensi wajib, harus didaftarkan ke kantor PVT di lingkungan Departemen Pertanian Republik Indonesia. Pendaftaran surat perjanjian lisensi sekaligus merupakan pencatatan hak yang mempunyai akibat hukum bagi pihak ketiga.

\section{Hukum Dasar Perlindungan Varietas Tanaman}

Perlindungan varietas tanaman merupakan suatu ketentuan dalam HAKI yang masih relatif baru dalam sejarah perlindungannya sebagai hak kebendaan immaterial yang diberikan kepada individu oleh negara. Di negara lain, seperti Amerika, meskipun tidak disebut secara khusus dalam peraturan negaranya, telah dikenal adanya peraturan mengenai perlindungan terhadap varietas tanaman. Peraturan tersebut berlaku tahun 1930 bersamaan dengan terbitnya The United States Patent Act 1930. Dan di Eropa, Undang-Undang yang berkaitan dengan perlindungan terhadap varietas tanaman dan hasilnya telah dikenal sejak abad ke-16.

Pada tahun 1961, beberapa negara di dunia telah menyepakati suatu konvensi internasional tentang perlindungan varietas tanaman, kesepakatan internasional termuat dalam International Convention for the Protection of New Varieties of Plants, yang lebih dikenal dengan istilah UPOV. UPOV merupakan akronim dari Union International pour la protection des obtentions vegetale.

Di Indonesi,perlindungan terhadap varietas tanaman sudah mulai diatur sejak tahun 1989 yaitu dalam peraturan HAKI di bidang hak paten. Pada Undang-Undang Paten Tahun 1989 disebutkan bahwa perlindungan paten tidak dapat diberikan terhadap makanan, minuman, dan varietas tanaman, khususnya bagi komoditi tanaman padi, jagung, ubi kayu, dan ubi jalar.65 Pada tahun 1997, Undang-Undang Paten tersebut mengalami amandemen yaitu berupa pencabutan atau penghapusan terhadap ketentuan pelarangan pemberian perlindungan terhadap makanan, minuman dan varietas tanaman. Sehingga pada Undang-Undang Paten 1997, makanan, minuman dan varietas tanaman dapat memperoleh perlindungan berupa hak paten.

Amandemen terhadap Undang-Undang Paten terjadi sebagai akibat keikutsertaan Indonesia dalam meratifikasi ketentuan TRIPs (Trade Related Aspects of Intellectual Property Rights), dimana dalam ketentuan TRIPs pada Pasal 27 ayat (3) huruf b diatur bahwa : However, member shall provide for the protection of plants varieties either by patens or by an effective sui generis system or by any combination thereof.66 
Berdasasrkan ketentuan TRIPs, disebutkan bahwa TRIPs mewajibkan seluruh negaranegara yang menjadi anggotanya untuk memberikan perlindungan terhadap varietas tanaman, baik melalui perlindungan paten, sistem sui generis yang efektif (misalnya melalui pemberian hak pemulia), ataupun dengan kombinasi antara system perlindungan paten dan sistem sui generis.Meskipun Undang-Undang Paten Tahun 1997 telah mengizinkan pemberian perlindungan paten terhadap tanaman, namun Undang-Undang Paten 1997 tidak dapat memberikan perlindungan menyeluruh terhadap aspek-aspek yang terdapat pada varietas baru Perlindungan terhadap varietas tanaman dengan menggunakan hak paten tidak dapat terus dilakukan, dengan alasan :

1. Pemegang paten akan memiliki kewenangan secara prinsip untuk melarang penggunaan kembali benih yang telah ditanam oleh petani, dengan konsekuensi akan muncul biaya tinggi bagi petani dan dominasi perusahaan benih besar akan semakin kuat.

2. Pemuliaan yang berdasarkan pada perlindungan varietas tanaman akan tersingkir, yakni ketika perlindungan paten tidak mendukung jenis invensi yang dihasilkan oleh petani tradisional tidak dimintakan paten dan digunakan secara bebas diantara kelompok petani tersebut.

3. Pemberian paten memiliki sifat akan adanya hak monopoli pada benih dan/atau tanaman yang menjadi objek produksi serta perdagangan benuh yang penting.

4. Pemberian paten akan mendukung standarisasi yang lebih tinggi serta memperkuat kecenderungan ke arah budidaya tunggal sehingga akan mengikis keanekaragaman hayati.

5. Pemberian paten juga mendukung bertambahnya kecenderungan monopoli pada pemilikan tanah dan industri benih, yang memungkinkan petani kecil dan pemulis tradisional merasakan dampak terburuk.

Selain perlindungan dengan hak paten, pengaturan secara khusus mengenai perlindungan terhadap varietas tanaman dilakukan sejak tahun 1990 dengan diterbitkannya Undang-Undang Nomor 5 Tahun 1990 tentang Konservasi Sumberdaya Alam Hayati dan Ekosistemnya. Kemudian pada tahun 1992, diterbitkan

Undang-Undang Nomor 12 Tahun 1992 tentang Sistem Budidaya Tanaman yang mendorong kegiatan pemuliaan tanaman, dimana dalam Pasal 55 Undang-Undang Nomor 12 Tahun 1992 dinyatakan bahwa :

1.Kepada penemu teknologi tepat serta penemu teori dan metode ilmiah baru di bidang budidaya tanaman dapat diberikan penghargaan oleh pemerintah

2.Kepada penemu jenis baru dan/atau varietas unggul dapat diberikan penghargaan oleh pemerintah serta mempunyai hak memberi nama pada temuannya.

3.Setiap orang atau badan hukum yang tanamannya memiliki keunggulan tertentu dapat diberikan penghargaan oleh pemerintah.

4.Ketentuan mengenai pemberian penghargaan sebagai maksud dalam ayat (1), ayat (2) dan ayat (3) diatur lebih lanjut oleh pemerintah.

Ketentuan dalam Undang-Undang Nomor 12 Tahun1992 tidak mengatur adanya perlindungan terhadap hak-hak yang dimiliki pihak pemulia tanaman, sehingga para pemulia tanaman tidak mengetahui keuntungan/manfaat yang diperoleh apabila varietas temuannya diperbanyak atau dijual, dan apa sanksi bagi pihak yang menjual atau menggunakan varietas 
temuanya tanpa persetujuan dari pihak pemulia untuk tujuan komersial. Berdasarkan ketentuan dalam Undang-Undang Nomor 12 Tahun 1992, pihak pemulia hanya memperoleh penghargaan dari pemerintah, sebagai balas jasa dari hasil penemuan varietas baru.

Ketentuan lain yang mengatur tentang pemberian penghargaan terhadap penemuan varietas unggul terdapat dalam Pasal 45 Peraturan Pemerintah No.44 Tahun 1995 tentang Pembenihan Tanaman yang menyatakan bahwa Menteri memberikan penghargaan kepada penemu varietas unggul dan/atau teknologi di bidang perbenihan. Pada tanggal 20 Desember 2000, diterbitkan Undang-UndangNomor 29 Tahun 2000, dimana Undang-Undang tersebut mengatur secara terperinci mengenai perlindungan terhadap varietas tanaman.

Latar belakang lahirnya Undang-Undang varietas tanaman yang mengatur secara khusus mengenai perlindungan terhadap varietas tanaman di Indonesia tidak terlepas dari tuntutan sekaligus konsekuensi Indonesia atas keikutsertaannya menandatangani kesekapatan GATT/WTO 1994, dimana salah satu ketentuannya memuat mengenai kesepakatan TRIPs (Trade Aspects if Intellectual Property Rgihts). Keikutsertaan Indonesia meratifikasi kesepakatan TRIPs, mengakibatkan Indonesia harus menyelaraskan peraturan perundang-undangan khususnya di bidang HAKI dengan persetujuan TRIPs yang di dalamnya terdapat ketentuan mengenai perlindungan terhadap varietas tanaman.

Selain itu adanya pengaturan secara khusus mengenai perlindungan terhadap varietas tanaman ini akan meningkatkan minat dan peran serta serta baik secara perorangan maupun badan hukum untuk melakukan kegiatan pemuliaan tanaman dalam rangka menghasilkan varietas tanaman baru yang unggul, karena para pemulia atau pemegang hak perlindungan terhadap varietas tanaman akan memiliki hal tertentu yang memiliki perlindungan hukum secara memadai.

\section{Subjek Hukum Yang Dapat Melakukan Proses Pendaftaran Hak Perlindungan Varietas Tanaman.}

Kegiatan pemuliaan tanaman di Indonesia terbuka terhadap semua pihak, baik perorangan maupun badan hukum dari instansi pemerintah dan pihak swasta. Keterbukaan peluang dalam kegiatan pemuliaan tanaman bagi pihak swasta perlu dilakukan, mengingat tingginya tingkat kebutuhan terhadap varietas tanaman dari berbagai komoditi yang sampai saat ini masih belum dapat terpenuhi.

Varietas tanaman yang selama ini terbentuk lebih banyak dihasilkan oleh para pemulia tanaman yang berasal dari instansi pemerintah dan dari kalangan perguruan tinggi, sehingga jumlah masih terbatas. Sedangkan pihak swasta yang terlibat pada umumnya lebih tertarik untuk menghasilkan Menurut Pasal 1 angka 3 Undang-Undang Nomor 29 Tahun 2000 tentang Perlindungan Varietas Tanaman disebutkan bahwa varietas tanaman adalah sekelompok tanaman dari suatu jenis atau spesies yang ditandai oleh bentuk tanaman, pertumbuhan tanaman, daun, bunga, buah, biji, dan ekspresi karakteristik genotipe atau kombinasi genotipe yang dapat membedakan dari jenis atau spesies yang sama oleh sekurang-kurangnya satu sifat yang menentukan dan apabila diperbanyak tidak mengalami perubahan.

Berdasarkan pengertian di atas, maka dapat diketahui bahwa varietas tanaman yang dihasilkan harus berbeda dengan varietas tanaman yang lain yang ditandai dengan perbedaan bentuk fisik sampai perbedaan karakteristik tanaman yang bersifat komersial (commercial variety) seperti tanaman jagung hibrida, sayuran dan buah-buahan semusim, bahkan ada pula industri benih yang hanya melakukan perbanyakan dari Menurut Pasal 1 angka 3 Undang- 
Undang Nomor 29 Tahun 2000 tentang Perlindungan Varietas Tanaman disebutkan bahwa varietas tanaman adalah sekelompok tanaman dari suatu jenis atau spesies yang ditandai oleh bentuk tanaman, pertumbuhan tanaman, daun, bunga, buah, biji, dan ekspresi karakteristik genotipe atau kombinasi genotipe yang dapat membedakan dari jenis atau spesies yang sama oleh sekurang-kurangnya satu sifat yang menentukan dan apabila diperbanyak tidak mengalami perubahan.

Berdasarkan pengertian di atas, maka dapat diketahui bahwa varietas tanaman yang dihasilkan harus berbeda dengan varietas tanaman yang lain yang ditandai dengan perbedaan bentuk fisik sampai perbedaan karakteristik tanaman yang telah ada.

Permohonan pendaftaran hak Perlindungan Varietas Tanaman (PVT) secara tertulis dengan mempergunakan bahasa Indonesia dan membayar biaya yang besarnya ditetapkan oleh Menteri. Permohonan pendaftaran hak Perlindungan Varietas Tanaman (PVT) hanya dapat diajukan untuk suatu varietas tanaman, dimana permohonan dapat diajukan oleh :

\section{Pemulia}

Pemulia yang menghasilkan suatu varietas tanaman yang baru berhak untuk mendapatkan imbalan yang layak dengan memperhatikan manfaat ekonomi yang dapat diperoleh dari varietas tanaman. Imbalan tersebut dapat dibayarkan dengan ketentuan seperti yang diatur dalam Pasal 8 ayat (2) Undang-Undang Nomor 2019 Tahun 2000 yaitu :

a.Dalam jumlah tertentu dan sekaligus

b.Berdasarkan persentase

c.Dalam bentuk gabungan antara jumlah tertentu dan sekaligus dengan hadiah atau bonus

d.Dalam bentuk gabungan antara persentase dengan hadiah atau bonus yang bersarnya ditetapkan sendiri oleh pihak-pihak yang bersangkutan.

Ketentuan pemberian imbalan sama sekali tiak akan menghapus hak pemulia, agar namanya tetap dicantumkan dalam sertifikat pemberian hak Perlindungan Varietas Tanaman. Seorang pemulia yang ingin melakukan pendaftaran hak Perlindungan Varietas Tanaman (PVT) berkewajiban untuk:

a.Melaksanakan hak Perlindungan Varietas Tanaman (PVT) di Indonesia

b.Membayar biaya tahunan Perlindungan Varietas Tanaman (PVT)

c.Menyediakan dan menunjukkan contoh benih varietas yang telah mendapatkan hak Perlindungan Varietas Tanaman (PVT) di Indonesia.

Akan tetapi, ketentuan dapat dikecualikan apabila dalam melaksanakan hak Perlindungan Varietas Tanaman (PVT)-nya seorang pemulia mendapatkan kendala baik secara teknis maupun ekonomis dalam mengembangkan varietas tanaman di Indonesia. Pengecualian hanya dapat disetujui kantor Perlindungan Varietas Tanaman (PVT) apabila pihak pemulia sebagai pemegang hak Perlindungan Varietas Tanaman (PVT) mengajukan permohonan tertulis yang disertai alasan-alasan dan bukti yang diberikan oleh instansi yang berwenang.

\section{Orang atau badan hukum yang mempekerjakan pemulia aau yang memesan varietas dari pemulia}

Para pihak yang mempekerjakan pemulia ini dapat berasal dari perorangan, instansi pemerintah maupun pihak swasta. Para pihak tersebut yang memberikan dana dan fasilitas yang 
diperlukan pihak pemulia untuk menghasilkan suatu varietas tanaman yang baru. Kerjasamana antara kedua belah pihak dituangkan dalam perjanjian yang dibuat secara khusus. Berdasarkan perjanjian yang telah disepakati bersama, varietas tanaman yang dihasilkan pemulia selanjutnya akan dialihkan kepada pihak yang mendanai kegiataan pemuliaan tanaman. Orang atau badan hukum selaku kuasa dalam mengajukan permohonan pendaftaran hak Perlindungan Varietas Tanaman harus menyertakan surat kuasa khusus dengan mencantumkan nama dan alamat lengkap kuasa yang berhak.

\section{Ahli waris}

Pihak ahli waris dapat merupakan ahli waris dari pemulia tanaman maupun ahli waris dari pihak yang mempekerjakan pemulia atau yang memesan varietas dari pemulia. Dalam mengajukan permohonan pendapatan hak Perlindungan Varietas Tanaman (PVT), seorang ahli waris harus membawa serta dokumen resmi sebagai bukti bahwa dirinya benar merupakan ahli waris dari pemulia tanaman maupun ahli waris dari pihak yang mempekerjakan pemulia atau yang memesan varietas dari pemulia.

\section{Konsultan Perlindungan Varietas Tanaman (PVT)}

Permohonan pendaftaran hak Perlindungan Varietas Tanaman (PVT) dapat diajukan oleh pihak pemohon yang tidak bertempat tinggal atau berkedudukan tetap di Indonesia. Mereka dapat membuat permohonan melalui konsultan Perlindungan Varietas Tanaman (PVT) di Indonesia selaku kuasa. Seorang konsultan Perlindungan Varietas Tanaman (PVT) berkewajiban untuk :

a.Terdaftar di kantor Perlindungan Varietas Tanaman (PVT)

b.Menjaga kerahasiaan varietas dan seluruh dokumen permohonan hak Perlindungan Varietas Tanaman (PVT), sampai dengan tanggal diumumkannya permohonan hak Perlindungan Varietas Tanaman (PVT) yang bersangkutan.

Pekerjaan seorang konsultan Perlindungan Varietas Tanaman (PVT) memerlukan pengetahuan, sikap dan keterampilan yang khusus agar proses permohonan hak Perlindungan Varietas Tanaman (PVT) dan langkah-langkah selanjutnya dapat dilaksanakan dengan sebaikbaiknya dengan tidak melanggar ketentuan peraturan yang terkait serta tidak merugikan pihak yang ingin mengajukan permohonan hak Perlindungan Varietas Tanaman (PVT). Kewajiban konsultan Perlindungan Varietas Tanaman (PVT) untuk menjaga kerahasiaan varietas, berlaku pula kepada para pihak terkait yang dipekerjakan oleh konsultan tersebut, misalnya penerjemah dan sebagainya. Kewajiban untuk menjaga kerahasiaan varietas akan berakhir pada saat permohonan hak Perlindungan Varietas Tanaman (PVT) mulai diumumkan oleh kantor Perlindungan Varietas Tanaman (PVT).

Konsultan Perlindungan Varietas Tanaman (PVT) merupakan perorangan maupun lembaga yang secara khusus memberikan jasanya yang berkaitan dengan pengajuan permohonan hak Perlindungan Varietas Tanaman (PVT). Tujuan pengadaan lembaga ini adalah untuk memberikan kemudahan bagi pemulia ataupun para pemohon Perlindungan Varietas Tanaman (PVT) yang tidak memahami segi hukum ataupun segi administrasi mengenai hak Perlindungan Varietas Tanaman (PVT), khususnya bagi para pihak pemohon yang berada di luar Indonesia yang tidak mempunyai perwakilan seperti badan hukum yang resmi di Indonesia. Persyaratan untuk menjadi seorang konsultan Perlindungan Varietas Tanaman (PVT) diatur secara khusus 
oleh pemerintah, dimana persyaratan tersebut meliputi syarat kelengkapan administrasi, kelengkapan fasilitas perkantoran, kriteria pengetahuan dan keterampilan teknis staf yang memadai, serta dedikasi dan kemampuan tugas dan fungsi konsultan Perlindungan Varietas Tanaman (PVT) yang dinilai secara periodik.

\section{Instansi Yang Berwenang Mengelola Pendaftaran Hak Perlindungan Varietas Tanaman}

Agar kebutuhan varietas tanaman dari berbagai komoditi dapat terpenuhi, maka diperlukan kerjasama yang baik dari semua kalangan, bukan saja keterlibatan pihak pemulia tanaman dari kalangan instansi pemerintah ataupun dari kalangan perguruan tinggi saja, melainkan juga dibutuhkan keterlibatan industri benuh dari perusahaan swasta. Dalam proses pemuliaan tanaman, para pihak yang ingin mendaftarkan hak perlindungan terhadap varietas tanaman dapat mengajukan permohonan ke kantor perlindungan varietas tanaman yaitu suatu unit organisasi di lingkungan Departemen Pertanian dimana unit tersebut mempunyai tugas dan kewenangankhusus di bidang perlindungan varietas tanaman.

Dalam kantor Perlindungan Varietas Tanaman (PVT) tersebut terdapat pejabat khusus yang disebut pemeriksa perlindungan varietas tanaman yaitu pejabatpemerintah yang berdasarkan keahliannya diangkat oleh Menteri Pertanian dan ditugaskan untuk melakukan pemeriksaan substantif dan memberikan rekomendasi atas permohonan hak perlindungan varietas tanaman. Pemeriksaan substantif yang dilakukan pemeriksa perlindungan varietas tanaman akan meliputi pemeriksaan kebaruan, keunikan, keseragaman, dan kestabilan varietas tanaman yang dimohonkan hak Perlindungan Varietas Tanaman (PVT). Dalam melaksanakan tugasnya kantor Perlindungan Varietas Tanaman (PVT) dapat meminta bantuan ahli maupun fasilitas yang diperlukan termasuk mencari informasi dari institusi lain baik dari dalam negeri maupun dari luar negeri.

Kantor perlindungan varietas tanaman akan menerbitkan daftar umum perlindungan varietas tanaman yaitu daftar catatan resmi dari seluruh tahapan dan kegiatan pengelolaan perlindungan varietas tanaman. Selain itu, kantor perlindungan varietas tanaman tersebut juga menerbitkan berita resmi perlidungan varietas tanaman yaitu suatu media informasi komunikasi resmi dari kegiatan pengelolaan perlindungan varietas tanaman yang diterbitkan secara berkala untuk tujuan kepentingan umum.

\section{Kesimpulan}

Pemegang hak PVT atau pemegang lisensi atau pemegang lisensi wajib berhak menuntut ganti rugi melalui Pengadilan Negeri kepada siapapun yang dengan sengaja dan tanpa hak melakukan perbuatan penyalahgunaan hak perlindungan terhadap varietas tanaman yang tidak dimilikinya. Tuntutan ganti rugi yang diajukan dapat diterima apabila terbukti bahwa varietas yang digunakan adalah varietasyang telah mendapatkan perlindungan terhadap varietas tanaman (hak PVT). Undang-Undang Nomor 29 Tahun 2000 Tentang Perlindungan Varietas Tanaman telah memberikan perlindungan hukum terhadap hak moral dan hak ekonomi yang dimiliki oleh pemulia. Sebelum berlakunya Undang-Undang Nomor 29 Tahun 2000 Tentang Perlindungan Varietas Tanaman, tidak ada perlindungan hak ekonomi bagipemulia. Ketentuan dalam UndangUndang Nomor 29 Tahun 2000 Tentang Perlindungan Varietas Tanaman masih sangat terbatas dalam memberikan perlindungan hukum terhadap hak petani (farmer's rights)dan belum memberikan perlindungan hukum terhadap praktik-praktik tradisional petani. Penulis menyarankan agar Undang-Undang No. 29 Tahun 2000 tentang Perlindungan Varietas Tanaman direvisi dengan memasukkan ketentuan-ketentuan yang belum terdapat sebelumnya. Hal ini 
dimaksudkan untuk menjamin kepastian hukum, dan memberikan perlindungan hukum yang lebih baik kepada pemulia dan petani.

\section{DAFTAR PUSTAKA}

\section{A.Buku}

Andi Hamzah, Kamus Hukum, Ghalia Indonesia, Jakarta, 1986

ApelDoorn, Pengantar Ilmu Hukum, Pradnya Paramita, Jakarta, 1996

Barizah, Nurul, Perlindungan Varietas Tanaman, Sistem Budi Daya Tanaman dan Ketahanan Pangan di Indonesia, Ghalia Indonesia, Jakarta, 2006

Damian. Eddy, Hak Kekayaan Intelektual Suatu Pengantar, PT. alumni, Bandung, 2002

Djaja, Ermansyah, Panduan Permohonan Pendaftaran dan Perlindungan Varietas Tanaman, IPB, Bogor, 2008.

Djumhana, M. dan R. Djubaedillah., Hak Milik Intelektual Sejarah, Teori dan Prakteknya Di Indonesia, PT. Citra Aditya Bhakti, Bandung, 2003

-------; Hak Milik Intelektual, PT. Citra Aditya Bhakti, Bandung, 2003

Gautama, Sudargo, Hak Milik Intelektual Indonesia dan Perjanjian Internasional TRIPS, GATT, Putaran Uruguay (1994) PT. Citra Aditya Bakti, Bandung, 1994

Gambiro. Ita, Pemindahan Teknologi dan Pengaturannya Dalam Peraturan Perundangan, Aspek-Aspek Hukum Dari Pengalihan Tenologi, BPHN, Binacipta, Jakarta, 1991

Hata, Perdagangan Internasional Dalam Sistem GATT dan WTO Aspek-Aspek Hukum dan Non Hukum, Refika Aditama, Bandung, 2006.

Heliantoro, Perjanjian Lisensi Dalam Menunjang Pembangunan,Tarsito, Bandung, 1998

Huijbers, T, Filsafat Hukum Dalam Lintas Sejarah, Kanisius, Yogyakarta, 1982.

Ibrahim, J, Teori \& Metodologi Penelitian Hukum Normatif, Bayu Media, Surabaya, 2006

Kesowo. Bambang, Pengetahuan Umum Hak Atas Kekayaan Intelektual (HAKI) di Indonesia, Akademika Presindo, Jakarta, 2004

Kantaatmadja, Mieke Komar dan Ahmad. M. Ramli., Perlindungan Atas Hak Kekayaan Intelektual Masa Kini dan Tantangan Menghadapi Era globalisasi Abad 21, Alumni, Bandung, 2005

Krisnwati, Andriana dan Gazalba Saleh., Perlindungan Hukum Varietas Baru

Tanaman Dalam Perspektif Hak Paten dan Hak Pemulia, PT. Raja Grafindo

Persada, Jakarta, 2004 